\title{
ATTACHMENT ANAK TERLANTAR DENGAN PENGASUH DI LEMBAGA KESEJAHTERAAN SOSIAL ANAK RUMAH PENGHARAPAN BARU BANDUNG BARAT
}

\author{
Yosua Yabes Togatorop \\ Politeknik Kesejahteraan Sosial Bandung, yosuayabes@gmail.com \\ Dorang Luhpuri \\ Politeknik Kesejahteraan Sosial Bandung, dluhpuri@yahoo.com \\ Aep Rusmana \\ Politeknik Kesejahteraan Sosial Bandung, aeprusmana6@gmail.com
}

\begin{abstract}
Attachment is an strong emotional bond between person which is discriminative. This research aims to know the image of attachment of abandoned child with caregiver at LKSA Rumah Pengharapan Baru which included the characteristics of respondents, trust of respondent, communication of respondents and alienation of respondents. This research used descriptive analysis method with quantitative approach.The population in this research is 24 abandoned children whose age range is 10 to 18 years old and live in LKSA Rumah Pengharapan Baru Sampling technique which used in this research is census. The compiling data technique used in this research is questionnaire and documentation study. The validity of instrument is tested by Product Moment Pearson Correlation and the reliability of instrument is tested by Croncbach Alpha. The measuring instrument is using Likert Scale which provides four alternative answers namely, "Selalu", "Sering”, "Kadang-kadang", "Hampir Tidak Pernah" and "Tidak Pernah" in every positive and negative statements, The result of the research indicates that attachment of abandoned children with caregiver at LKSA Rumah Pengharapan Baru is in medium category. The result is known from the trust aspect in high category whose score 917, communication aspect in medium category whose score 685 and alienation in medium category whose score 507. The result indicates a problem which needs a program to increase communication an to decrease alienation aspect.
\end{abstract}

Keywords:

Attachment; Abandoned Children; Caregiver; LKSA

\begin{abstract}
Abstrak
Attachment merupakan suatu ikatan emosional yang kuat antara individu satu dengan yang lain yang bersifat diskriminatif. Penelitian ini bertujuan untuk mengetahui gambaran attachment anak terlantar dengan pengasuh di LKSA Rumah Pengharapan Baru yang mencakup karakteristik responden, kepercayaan responden (trust), komunikasi (communication) dan keterasingan responden (alienation). Penelitian ini
\end{abstract}


menggunakan metode analisis statistik deskriptif dengan pendekatan kuantitatif. Populasi dalam penelitian ini adalah 24 anak terlantar berusia 10-18 tahun yang tinggal di LKSA Rumah Pengharapan Baru. Teknik penarikan sampel dalam penelitian ini adalah sensus atau jenuh. Teknik pengumpulan data yang digunakan dalam penelitian ini adalah angket dan studi dokumentasi. Pengujian validitas alat ukur menggunakan Product Moment Pearson Correlation sedangkan untuk uji reliabilitas menggunakan rumus cronchbach alpha. Alat ukur yang digunakan adalah skala Likert yang menyediakan empat alternatif jawaban yaitu "Selalu", "Sering", "Kadang-kadang", "Hampir Tidak Pernah" dan "Tidak Pernah" pada setiap pernyataan positif dan negatif. Hasil dari penelitian ini menunjukkan attachment anak terlantar dengan pengasuh di LKSA Rumah Pengharapan Baru berada pada rentang sedang yang diketahui dari aspek kepercayaan yang berada pada rentang tinggi dengan skor 917, aspek komunikasi berada pada rentang sedang dengan skor 685 dan aspek keterasingan dalam rentang sedang dengan skor 507. Hasil tersebut menunjukkan masalah sehingga dibutuhkan sebuah program yang dapat meningkatkan aspek komunikasi dan mengurangi aspek keterasingan.

\section{Kata Kunci:}

Attachment; Anak Terlantar; Pengasuh; LKSA 


\section{PENDAHULUAN}

Kekerasan terhadap anak meningkat setiap tahunnya. Pada tahun 2018 Komisi Perlindungan Anak Indonesia mencatat ada 4.885 kasus kekerasan terhadap anak, bertambah 306 kasus dibandingkan tahun 2017 yang berjumlah 4.579 kasus. Ketua Komisi Perlindungan Anak Indonesia menyatakan bahwa kasus terkait masalah keluarga dan pengasuhan anak terdapat 857 kasus dimana masalah ini menduduki kedua tertinggi diantara masalah lainnya. Fakta tersebut memberikan pandangan bahwa kekerasan yang didapatkan anak sering terjadi pada lingkungan sekitarnya. Anak yang seharusnya mendapatkan pengasuhan yang layak justru mendapatkan kekerasan dari orang terdekatnya yang seharusnya melindungi dan memberikan kasih sayang kepada anak. Akibatnya anak tidak bisa berkembang dengan baik dan tidak berdaya atau disebut dengan terlantar.

Anak terlantar merupakan salah satu kelompok penyandang masalah kesejahteraan sosial (PMKS) yang sering mengalami permasalahan dalam dirinya sendiri maupun terhadap lingkungannya sebagai dampak dari keadaannya. Anak terlantar di Jawa Barat tercatat ada 135.787 anak dan 345 anak diantaranya terdapat di Kabupaten Bandung Barat (Badan Pusat Statistik Jawa Barat, 2018). Anak terlantar memiliki beberapa masalah yang berkaitan dengan kebutuhan seperti perlindungan dan kasih sayang (Brown dan Swason dalam Huraerah, 2007) yang penting untuk menumbuhkan dan mengemabngkan kehidupan mental yang sehat.

Kebutuhan tersebut dapat terpenuhi melalui suatu hubungan yang lekat atau sering disebut attachment. John Bowlby (1969) menyatakan bahwa attachment adalah keterhubungan sescara psikologis anak dengan pengasuhnya. Sejalan dengan hal itu Mary Ainsworth dalam Ervika (2005) menegaskan bahwa attachment atau kelekatan dibentuk sangat berpengaruh penting bagi anak. Ia berpendapat bahwa attachment merupakan dasar untuk seseorang membentuk hubungan lainnya.

Anak terlantar yang tidak mendapatkan pengasuhan yang layak cenderung memiliki gangguan attachment. Erikson dalam Yusuf Efendi (2010:87) menyatakan bahwa gangguan attachment disebabkan oleh perpisahan yang tiba tiba, kekerasan terhadap anak, pengasuhan yang tidak stabil dan masalah psikologis yang dialami oleh pengasuh/orangtua. Pendapat tersebut menyatakan bahwa peran orangtua sangat berpengaruh besar terhadap anak.

Greenberg dan Armsden (2009) mengungkapkan bahwa attachment dapat dilihat melalui 1) afeksi positif/ pengalaman kognisi terhadap kepercayaan kepada figur lekat dalam hal aksesibilitas dan responsivitasnya, 2) afeksi negatif /pengalaman kognisi dari kemarahn dan atau hasil keputusasaan yang tidak responsif atau respon yang tidak menentu. Pendapat tersebut selanjutnya didapatkan aspek attachment yakni 1) Kepercayaan yang mengacu pada keyakinan orang lain akan memenuhi kebutuhannya, 2) Komunikasi yang mengacu pada hubungan timbal balik dan 3) Keterasingan yaitu perasaan tidak aman atau terabaikan dari figur lekatnya.

Beberapa hal tersebut menjadi alasan untuk peneliti melakukan penelitian. Penelitian bertujuan untuk mencari gambaran empirik terkait dengan attachment yang dimiliki anak dengan pengasuh di LKSA 
Rumah Pengharapan Baru. Adapun rumusan masalah penelitian ini adalah 1) Bagaimana karakteristik responden? 2) Bagaimana kepercayaan anak kepada pengasuh? 3) Bagaimana komunikasi anak dengan pengasuh? 4) Bagaimana keterasingan yang dirasakan anak?.

\section{METODE}

Metode yang digunakan dalam penelitian ini adalah deskriptif dengan pendekatan kuantitatif. Teknik pengambilan sampel yang digunakan adalah sensus atau jenuh. Hal ini dikarenakan jumlah populasi yang relatif kecil hanya 24 orang atau kurang dari 30 orang sehingga seluruh populasi dijadikan responden (Sugiyono, 2012). Pengumpulan data dilakukan dengan penyebaran angket kepada anak terlantar yang tinggal di asrama LKSA dan studi dokumentasi berupa profil lembaga melalui daring. Teknik analisa data yang digunakan adalah statistika deskriptif

Instrumen yang digunakan dalam penelitian ini adalah Inventory of Parents and Peers Attachment (IPPA) yang disusun oleh Armsden dan Greenberg namun dilakukan beberapa penyesuaian yakni, 1) Instrumen yang digunakan hanya bagian Mother, 2) Pernyataan disusun ulang sesuai aspek, 3) Instrumen dialihbahasakan menjadi Bahasa Indonesia. Instrumen diuji validitasnya dengan Product Moment dan Reliabilitasnya dengan Rumus Cronhbach's Alpha dengan nilai alpha sama dengan 0,966 .

\section{HASIL PENELITIAN}

Penelitian yang sudah dilakukan memberikan hasil sebagai berikut

\section{Karakteristik Responden}

Responden dalam penelitian ini berjumlah 24 orang anak. Responden dengan jenis kelamin perempuan berjumlah 13 orang atau $54 \%$ dari jumlah keseluruhan sedangkan jenis kelamin laki-laki berjumlah 11 orang atau $46 \%$ dari jumlah keseluruhan. Jenis kelamin responden pada penelitian ini hampir berimbang satu sama lainnya.

Rentang usia responden pada penelitian ini adalah $10-18$ tahun. Adapun lebih jelas usia responden dimuat dalam Tabel 1 .

Tabel 1. Karakteristik Responden Berdasarkan Usia

\begin{tabular}{|c|c|c|c|}
\hline No & $\begin{array}{c}\text { Usia } \\
\text { (Tahun) }\end{array}$ & $\begin{array}{l}\text { Jumlah } \\
\text { (Jiwa) }\end{array}$ & $\begin{array}{c}\text { Presentase } \\
(\%)\end{array}$ \\
\hline 1 & 10 & 1 & 4.16 \\
\hline 2 & 11 & 2 & 8.33 \\
\hline 3 & 12 & 5 & 20.83 \\
\hline 4 & 13 & 1 & 4.16 \\
\hline 5 & 14 & 4 & 16.67 \\
\hline 6 & 15 & 1 & 4.17 \\
\hline 7 & 17 & 5 & 20.83 \\
\hline 8 & 18 & 5 & 20.83 \\
\hline \multicolumn{2}{|r|}{ Total } & 24 & 100.00 \\
\hline
\end{tabular}

Tabel 1 menunjukkkan terdapat 8 orang anak atau $34 \%$ anak masih dalam masa akhir kanak kanak. Anak lainnya masuk dalam masa remaja dengan jumlah 16 orang atau 64\% anak. Masa tersebut merupakan masa dimana anak mulai menjajaki dunia sosial yang lebih luas dan kompleks (Santrock, 2003:50). Attachment anak dengan orangtua diyakini membantu remaja terkait kompetensi sosial dan kesejahteraan sosial yang tercermin 
dalam harga diri, penyesuaian emosional dan kesehatan fisik (Allen dalam Santrock, 2003:60) oleh karena itu attachment sangatlah penting terhadap masa perkembangan anak.

Adapun responden ditinjau dari lama tinggal di asrama sebagai berikut.

Tabel 2 Responden Berdasarkan Lama Tinggal di Asrama

\begin{tabular}{|r|l|r|r|}
\hline No. & $\begin{array}{l}\text { Lama } \\
\text { Tinggal } \\
\text { (Tahun) }\end{array}$ & $\begin{array}{l}\text { Jumlah } \\
\text { (Jiwa) }\end{array}$ & $\begin{array}{l}\text { Presentase } \\
(\%)\end{array}$ \\
\hline 1 & 1 & 1 & 4.16 \\
\hline 2 & 2 & 3 & 12.48 \\
\hline 3 & 4 & 1 & 4.16 \\
\hline 4 & 5 & 1 & 4.16 \\
\hline 5 & 6 & 3 & 12.48 \\
\hline 6 & 7 & 3 & 12.48 \\
\hline 7 & 8 & 1 & 4.16 \\
\hline 8 & 9 & 2 & 8.32 \\
\hline 9 & 10 & 4 & 16.64 \\
\hline 10 & 11 & 1 & 4.16 \\
\hline 11 & 12 & 2 & 8.32 \\
\hline 12 & 14 & 1 & 4.16 \\
\hline 13 & 15 & 1 & 4.16 \\
\hline & Total & 24 & 100.00 \\
\hline
\end{tabular}

Tabel 2 menunjukkan bahwa lama tinggal responden di LKSA Rumah Pengharapan Baru sangat beragam. Terdapat anak yang sudah lama tinggal di panti selama 15 tahun dan anak yang baru saja tinggal di panti selama 1 tahun. Anak paling banyak lama tinggal di panti selama 10 tahun atau dengan presentase $16.64 \%$. Apabila ditarik rata-rata dari data tersebut, didapatkan 7.7 tahun lama anak tinggal di panti. Hal ini sangatlah penting karena attachment terbentuk selama rentang manusia (Ainsworth, 1979) dan salah satunya dipengaruhi oleh intensitas pertemuan antara figur lekat dengan anak (Baradja, 2005:125). Semakin lama anak tinggal di panti maka mempengaruhi attachment yang terbentuk dengan pengasuhnya.

Tingkat pendidikan yang sedang ditempuh oleh masing-masing responden cukup beragam. Tingkatan pendidikan formal yang sedang dijalani yakni Sekolah Dasar, Sekolah Menengah Pertama dan Sekolah Menengah Atas. Responden yang menempuh pendidikan formal menandakan bahwa responden dinilai mampu untuk memahami pernyataan-pernyataan yang tersedia dalam instrumen. Hasil selanjutnya yakni rekapitulasi setiap aspek penelitian yang akan dijelaskan pada

\section{Aspek Kepercayaan}

Kepercayaan merupakan salah satu aspek dari attachment. Kepercayaan muncul apabila ada kenyamanan fisik dan rasa khawatir yang rendah akan masa depan. Kepercayaan yang terbentuk membuat anak memandang dunia sebagai tempat tinggal yang aman, baik dan menyenangkan. Adapun hasil dari jawaban responden terkait kepercayaan dimuat dalam garis kontinum berikut ini.

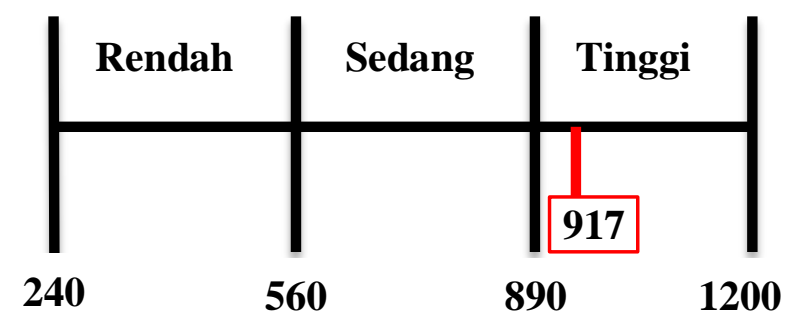

\section{Gambar 1: Garis Kontinum Aspek Kepercayaan}

Aspek kepercayaan dimuat dalam 10 pernyataan. Skor yang didapatkan dari jawaban seluruh responden adalah 917 atau dalam presentase adalah $76,42 \%$ dari skor ideal. Skor tersebut apabila dilihat melalui 
garis kontinum berada pada rentang 890 1200 atau dalam kategori Tinggi.

\section{Aspek Komunikasi}

Komunikasi merupakan salah satu komponen penting dalam membangun suatu hubungan. Komunikasi pada hal ini merujuk kepada komunikasi yang dilakukan oleh responden dengan pengasuh. Komunikasi yang baik menandakan bahwa anak mampu menciptakan kedekatan dengan figur lekat nya dan terbuka satu sama lain. Adapun rekapitulasi dari jawaban responden terkait aspek komunikasi adalah sebagai berikut.

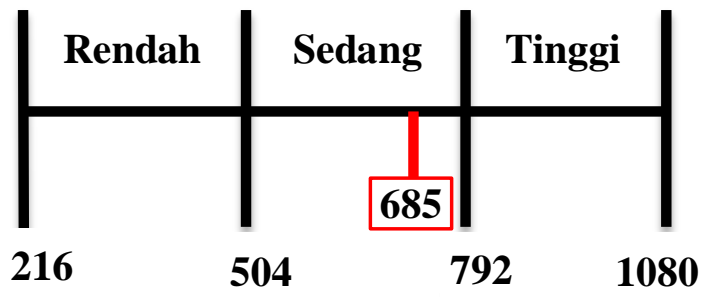

\section{Gambar 2: Garis Kontinum Aspek Komunikasi}

Aspek komunikasi diuraikan dalam 9 butir pernyataan. Skor yang didapatkan dari jawaban seluruh responden adalah 685 atau setara dengan presentase $63,42 \%$ dari skor ideal yaitu 1080. Hasil tersebut pada garis kontinum berada diantara skor 504 dan 792 sehingga dapat disimpulkan bahwa komunikasi masuk pada kategori Sedang.

\section{Aspek Keterasingan}

Keterasingan merupakan perasaan yang tidak aman atau nyaman. Perasaan ini muncul karena adanya penolakan dan pengabaian dari figur lekat. Anak yang terpisah dengan figur lekat karena kekerasan, penelantaran atau perceraian cenderung mengalami keterasingan. Aspek keterasingan dimuat dalam 6 butir pernyataan. Seluruh butir pernyataan merupakan pernyataan negatif/unfavorable. Pernyataan negatif diartikan sebagai pernyataan yang menandakan attachment yang tidak baik. Adapun jawaban responden sebagai berikut.

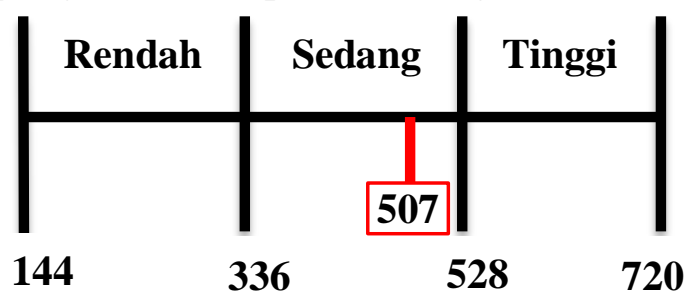

\section{Gambar 2: Garis Kontinum Aspek Keterasingan}

Skoring dari aspek keterasingan dilakukan secara terbalik. Artinya skor jawaban berturut turut Tidak Pernah, Jarang, Kadang-kadang, Sering dan Selalu dinilai dengan skor 5,4,3,2 dan 1. Hasil rekapitulasi menunjukkan bahwa skor dari keterasingan responden adalah 507 atau $70,42 \%$ dari skor ideal. Skor ini apabila dilihat melalui garis kontinum, berada pada posisi diantara 336 dan 528 atau pada kategori Sedang. Hal ini menandakan bahwa responden tidak terlalu merasakan keterasingan dengan pengasuh namun masih terdapat keterasingan diantara anak dengan pengasuh.

\section{PEMBAHASAN}

Penelitian yang dilakukan adalah mengenai attachment anak terlantar dengan pengasuhnya. Attachment adalah suatu hubungan psikologis antara anak dengan figur lekatnya. Attachment dalam penelitian ini dilihat melalui tiga aspek yaitu kepercayaan, komunikasi dan keterasingan yang dirasakan oleh anak (Greenberg, 1989). Adapun pembahasan dari masing-masing aspek sebagai berikut.

\section{Analisis Aspek Kepercayaan}

Aspek kepercayaan mengacu kepada rasa aman dan keyakinan bahwa orang lain, pada hal ini figur lekat, akan memnuhi kebutuhannya. Rasa saling percaya antara anak dengan pengasuh mendorong anak untuk 
lebih percaya diri dan bertindak hati hati(Chen dalam Desmita:2012). Aspek kepercayaan memiliki skor 917 dari skor ideal yaitu 1200. Kepercayaan anak terhadap pengasuh termasuk dalam kategori tinggi

Adapun temuan yang didapatkan bahwa dari 10 pernyataan, 8 diantaranya sudah dapat dicapai dengan baik. Dua pernyataan diantaranya belum mampu dicapai oleh responden. Pernyataan tersebut adalah pernyataan nomor 3 dan 5. Pernyataan nomor 3 terkait dengan "Jika mungkin, Saya ingin memiliki pengasuh yang lain" mengacu pada kepuasan anak terhadap pengasuhnya. Hal ini sejalan dengan pendapat Baradja (2005:125) bahwa kepuasan anak terhadap pengasuh berpengaruh terhadap attachment yang dibentuk anak. Hal ini dapat dilihat dari kemampuan figur lekat setiap kali anak membutuhkan sesuatu.

Pernyataan nomor 5 terkait dengan "Pengasuh Terlalu Berharap Tinggi pada Responden" mengacu pada pengasuh yang berharap kepada anak terlalu tinggi sehingga ada rasa terbebani pada anak. Apabila harapan tidak dapat dipenuhi oleh anak maka akan muncul rasa kecewa pada diri sendiri dan merasa tidak nyaman dengan pengasuh karena mengecewakan. Jadi dapat disimpulkan kepercayaan anak terhadap pengasuh tinggi namun pada komponen kepuasan dan harapan pengasuh masih belum baik.

\section{Analisis Aspek Komunikasi}

Aspek komunikasi berkaitan dengan hubungan timbal balik antara anak dengan pengasuh. Aspek ini mengacu pada persepsi anak bahwa pengasuh sensitif dan responsif terhadap kondisi emosi dan kualitas keterlibatan dan komunikasi verbal pengasuh (Greenberg:1989). Komunikasi yang baik menandakan ada hubungan yang dekat dengan pengasuhnya. Aspek komunikasi mendapatkan skor 685 dari skor ideal yaitu 1080. Apabila dilihat dalam garis kontinum maka komunikasi anak dengan pengasuh masuk dalam kategori sedang. Aspek komunikasi terdiri dari 9 butir, dimana 4 diantaranya sudah dapat dicapai namun 5 lainnya belum tercapai.

Salah satu dari 5 pernyataan itu adalah pernyataan nomor 1 terkait "Saya meminta pendapat pengasuh tentang hal yang saya pedulikan" yang mengacu pada persepsi anak terhadap pentingnya pandangan pengasuh pada dirinya. Pernyataan ini didukung dengan pernyataan nomor 4 terkait "Saya rasa pengasuh memiliki masalahnya sendiri, jadi saya tidak mau menambah bebannya dengan masalah Saya". Kedua pernyataan tersebut membuktikan anak belum mampu untuk terbuka dengan pengasuhnya. Attachment dilihat melalui aksesibilitas pengasuh (Armsden dan Greenberg, 1987:22). Aksesibilitas pengasuh yang kurang menjadi penghambat terbentuknya attachment yang baik dengan pengasuh

Pernyataan selanjutnya yang belum terpenuhi dengan baik yaitu pernyataan nomor 2 terkait "Saya rasa percuma untuk mengutarakan perasaan kepada pengasuh". Pernyataan ini menandakan perasaan tidak aman dan ketakutan akan tidak didengarkan atau dipedulikan perasaannya. Hal ini juga mengakibatkan anak belum mampu mencapai pernyataan nomor 6 terkait "Saya memberitahu pengasuh tentang masalah dan kesulitan yang saya alami" dan pernyataan nomor 8 terkait "Saya bisa mengandalkan pengasuh ketika ada yang mengganjal dalam hati saya". Ketiga pernyataan tersebut menandakan pengasuh belum menjadi tempat yang aman dan komunikasi yang terbentuk 
belum harmonis. Komunikasi yang kurang harmonis dapat berpengaruh buruk terhadap ikatan emosional antara anak dengan pengasuh (Sigrin dan Flora dalam Barocas, 2008).

\section{Analisis Aspek Keterasingan}

Aspek keterasingan merupakan salah satu hal penting lainnya dalam attachment. Keterasingan merupakan suatu perasaan yang tidak nyaman atau terabaikan oleh figure lekat (Armsden dan Greenberg, 1987). Perasaan tersebut muncul karena adanya penolakan dan pengabaian dari pengasuh atau figur lekat.. Aspek ini mendapatkan skor 507 dari skor 720. Hal ini diartikan attachment berdasarkan aspek keterasingan masuk dalam kategori sedang namun masih dirasakan keterasingan pada anak. Hal ini terlihat dari 5 pernyataan dari 6 pernyataan masih dirasakan oleh anak. Adapun 5 pernyataan tersebut adalah pernyataan nomor 2, 3, 4, 5 dan 6 .

Pernyataan nomor 5 terkait "Saya tidak cukup diperhatikan oleh pengasuh" menandakan bahwa anak belum meraskan perhatian yang cukup oleh pengasuhnya. Hal ini juga mendukung pernyataan nomor 6 terkait "pengasuh tidak mengerti apa yang saya alami akhir-akhir ini". Kedua pernyataan tersebut menunjukkan perhatian yang diberikan pengasuh belum ideal.

Pernyataan nomor 2, 3 dan 4 berkaitan kemarahan yang ada pada diri anak. Pernyataan nomor 2 terkait "Saya mudah marah ketika bersama pengasuh" menandakan bahwa keberadaan pengasuh membuat anak tidak nyaman. Pernyataan nomor 3 terkait "Saya marah lebih dari yang diketahui pengasuh" menandakan kemarahan anak atau rasa tidak nyaman tidak sepenuhnya muncul atau dipendam oleh anak. Pernyataan nomor 4 terkait "Saya marah dengan pengasuh" menandakan bahwa anak memiliki kekesalan kepada pengasuh. Kelima pernyataan tersebut menandakan ketidaknyamanan terhadap pengasuh. Ketidaknyamanan tersebut muncul dikarenakan oleh pengalaman kognisi atau afeksi yang negatif karena pengasuh yang tidak responsif atau respon yang tidak menentu (Armsden, 1987:22). Hal ini dikarenakan belum cukup diberikan atau respon belum diberikan ketika anak membutuhkannya. Idealnya pengasuh perlu merespon atau memberikan reaksi yang menunjukkan perhatian dan kasih sayang kepada anak ketika dibutuhkan (Baradja, 2005:125).

Ketiga aspek tersebut saling berkaitan satu sama lainnya terutama aspek komunikasi dan keterasingan. Kedua aspek ini saling mempengaruhi satu sama lain. Hal ini dapat dilihat dimana anak yang merasa asing dengan pengasuh tidak dapat membangun komunikasi yang baik dengan pengasuh. Attachment yang terbentuk menampilkan ketidaknyamanan dan penolakan anak terhadap pengasuh sehingga dapat dikatakan attachment yang terbentuk cenderung tidak aman/insecured (Ainsworth dalam Prior dan Glaser, 2006:25). Aspek kepercayaan masuk dalam kategori tinggi namun masih terdapat temuan berupa anak masih belum puas terhadap pengasuhnya. Hal tersebut tentunya menjadi masalah apabila dibiarkan.

Attachment anak dengan pengasuh di LKSA Rumah Pengharapan Baru perlu ditingkatkan. Peningkatan dapat dilakukan melalui pengurangan keterasingan dan peningkatan komunikasi antara anak dan pengasuh. Tujuan dari peningkatan tersebut dapat menumbuhkan kedekatan dengan pengasuh dan mengurangi kemarahan terhadap pengasuhnya. Kedekatan yang tumbuh sejalan dengan munculnya 
komunikasi yang harmonis sehingga anak dan pengasuh dapat terbuka satu sama lain. Komunikasi yang baik akan membentuk hubungan yang kuat antara anak dengan pengasuh sehingga attachment yang terbentuk antara anak dengan pengasuh aman/secured.

\section{KESIMPULAN}

Penelitian ini bertujuan untuk memberikan gambaran mengenai attachment anak terlantar dengan pengasuh di LKSA Rumah Pengharapan Baru Bandung Barat. Anak terlantar pada penelitian ini berjumlah 24 orang. Pengumpulan data dilakukan secara daring.

Karakteristik responden dalam penelitian ini berusia 10 sampai 18 tahun. Responden termasuk dalam masa perkembangan kanak-kanak akhir dan remaja. Anak terdiri dari 13 perempuan dan 11 lakilaki. Lama tinggal responden sangat beragam Terdapat anak paling lama tinggal di panti selama 15 tahun dan anak yang baru saja tinggal di panti selama 1 tahun. Apabila ditarik rata-rata dari data tersebut, didapatkan 7.7 tahun lama anak tinggal di panti. Seluruh responden sedang menempuh pendidikan formal yakni SD, SMP dan SMA.

Penelitian yang sudah dilakukan dari aspek kepercayaan didapatkan skor 917 $(76,42 \%)$ dari skor ideal 1200 dan masuk dalam kategori tinggi. Hasil analisis yang sudah dilakukan mendapatkan temuan bahwasanya kepercayaan anak terhadap pengasuh sudah baik namun masih didapatkan rasa tidak puas dan terbebani oleh ekspektasi tinggi pengasuh pada jawaban pernyataan responden.

Aspek selanjutnya yaitu komunikasi mendapatkan skor $685(63,42 \%)$ dari skor ideal 1080. Komunikasi anak dengan pengasuh masuk ke dalam kategori sedang. Analisis hasil aspek ini ditemui beberapa temuan yakni komunikasi yang terjadi belum maksimal. Hal ini dapat terlihat dari 9 pernyataan hanya 5 pernyataan yang dapat dicapai dengan baik. Komunikasi antara anak dengan pengasuh masih ditemukan bahwa anak belum bisa terbuka dengan pengasuh yang diakibatkan dari kurangnya aksesibilitas pengasuh. Aksesibilitas pengasuh yang kurang mengakibatkan anak tidak bisa mengungkapkan hal yang mengganjal pada dirinya atau kesulitan yang sedang dia alami. Hal ini dapat berpengaruh buruk pada ikatan emosional antara pengasuh dan anak.

Aspek selanjutnya adalah aspek keterasingan. Aspek ini mendapatkan skor 507 $(70,42 \%)$ dari skor ideal 720 dan masuk dalam kategori sedang. Hal ini dapat diartikan bahwa attachment anak dengan pengasuh cukup baik namun masih dirasakan keterasingan oleh anak. Hasil analisis aspek ini memberikan beberapa temuan. Pertama, perhatian pengasuh belum diberikan secara baik. Kedua responden merasakan kemarahan terhadap pengasuhnya. Kedua hal ini memiliki hubungan sebab akibat. Kemarahan muncul karena pengasuh yang tidak dapat memberikan respon yang baik berupa respon kasih sayang dan perhatian serta respon yang tidak konsisten.

Ketiga aspek attachment saling berkaitan terutama aspek komunikasi dan keterasingan. Hal ini dapat terlihat dari anak yang merasa asing dengan pengasuh sehingga tidak dapat membangun komunikasi yang baik. Anak yang tidak terbuka dan menghindari atau menolak keberadaan pengasuh merupakan indikasi attachment yang terbentuk tidaklah aman atau secured. Anak memerlukan kedekatan dengan 
pengasuh sehingga anak dapat terbuka satu sama lain dengan pengasuh sehingga dapat memperbaiki attachment antara anak dengan pengasuh.

\section{DAFTAR PUSTAKA}

Abu Huraerah. 2012. Kekerasan Terhadap Anak. Bandung : Nuansa

Armsden, G. C., \& Greenberg, M. T. (1987). The inventory of parent and peer attachment: Individual differences and their relationship to psychological wellbeing in adolescence. Journal of Youth and Adolescence, 16(5), 427-454. https://doi.org/10.1007/BF02202939.

Baradja. 2005. Psikologi Perkembangan: Tahapan-Tahapan dan Aspeknya. Jakarta: Studia Press.

Barocas. 2009. Adolescent Attachment to Parents and Peers. Dissertation Thesis. Diakses Agustus 2019 dari http://www.marial.emory.edu/pdfs/baroca s-\%thesisfinal.doc.

Greenberg, \& Armsden, G. (2009). Inventory of Parent and Peer Attachment. Bennett Chair of Prevention Research Director, Prevention Research Center. Human Development, 0112(August).

Prior, Vivien and Glaser, Danya. 2006. Understanding Attachment and Attachment Disorders. Philadelphia and London: Jessica Kingsley Publishers

Santrock. 2003. Adolescence :Perkembangan Remaja. Jakarta: Erlangga. .2011. Perkembangan Akan Remaja Jilid Dua. Cetakan Ke-7. Jakarta:Erlangga

Sri Lestari. 2012. Psikologi Keluarga: Penanaman Nilai dan Penanganan Konflik dalam Keluarga Edisi Pertama. Jakarta: Kencana

Sugiyono. 2015. Metode Penelitian Kuantitatif, Kualitatif dan $R \& D$. Bandung: ALFABETA Bandung
Yusuf Efendi. 2010. Psikologi Perkembangan Rentang Kehidupan. Bandung: PT Remaja Rosdakarya

\section{Sumber Lain}

Badan Pusat Statistik. 2016. Jumlah Permasalahan Sosial Menurut Jenis di Jawa Barat, 2016. Melalui https://jabar.bps.go.id/statictable/2018/03 /19/405/jumlah-permasalahan-sosialmenurut-jenis-di-jawa-barat-2016.html 08 Agustus 2019

Komisi Perlindungan Anak Indonesia. 2019. KPAI Sebut Pelanggaran Hak Anak Terus Meningkat. Melalui https://www.kpai.go.id/berita/kpai-sebutpelanggaran-hak-anak-terus-meningkat 08 Agustus 2019

Peraturan Menteri Sosial No. 08 Tahun 2012 tentang Pedoman Pendataan dan Pengelolaan Data Penyandang Masalah Kesejahteraan Sosial dan Potensi dan Sumber Kesejahteraan Sosial.

Profil LKSA Rumah Pengharapan Baru 2019

Undang-Undang RI No 4 tahun 1979 tentang Kesejahteraan Anak.

Undang-Undang RI No 23 tahun 2002 tentang Perlindungan Anak

Izmi Nafis Imtikhani. 2018. Kelekatan Remaja dengan Ibu Asuh di Panti Asuhan Putri 'Aisyiyah Cabang Margasari Kabupaten Tegal (Skripsi). Bandung: STKS Bandung Sofyan Syarifudin. 2018. Kelekatan Anak dengan Ibu yang Bekerja sebagai Karyawan Pabrik di Desa Kedungjati Kecamatan Bukateja Kabupaten Purbalingga (Skripsi). Bandung: STKS Bandung 